\title{
ICTs and Sustainable Development of Higher Education in Nigeria: Rewriting the Ugly Narrative
}

\author{
Patrick A. Edewor, Ph.D \\ David Imhonopi, Ph.D \\ Ugochukwu Moses Urim, M.Sc \\ Department of Sociology, Covenant University, \\ Ota, Ogun State, Nigeria \\ Email: patrick.edewor@covenantuniversity.edu.ng
}

Doi:10.5901/jesr.2014.v4n1p357

\begin{abstract}
The world has increasingly become a global clan through the instrumentality of ICT tools. The behemoth influence of ICTS can be felt in their dominance of all areas of human endeavours where they seem to define and refine interactions, social relations, work processes and standards. ICTs have recorded much success in many sectors and it is the contention in this paper that they can transmogrify the educational sector positively, particularly higher education. However, there are political and economic forces which have conflated to hamstring higher education of the much anticipated role it can play in the Nigerian society. In the presence of these albatrosses, even the integration of ICTs in higher education may not change the ugly narrative. However, ICTS have been identified as having the potential to change the complexion and content of higher education if the tools are put to work. It is expected that government will provide the required political and economic wherewithal needed for the easy adoption of ICT tools in driving higher education processes and objectives in Nigeria.
\end{abstract}

Keywords: ICTs, Higher Education, Globalisation, Society, Nigeria

\section{Introduction}

Information and Communication Technology (ICT) has become, within a very short time, one of the basic building blocks of modern society. ICTs have successfully changed the social, economic and political spaces globally. Through globalisation, ICTs have reduced the world to a global clan. Globalisation has assumed a cyclopean force driving human civilisation by the scruff (Imhonopi, \& Urim, 2013; Imhonopi \& Urim, 2011a, 2011b; Okafor, Imhonopi \& Urim, 2011). Similarly, ICTs have enabled the globalised world become greatly interconnected, interdependent and without borders (Salawu, 2008). ICTs are changing the world rapidly, creating a distance-less and borderless world of instantaneous communication (Spence \& Smith, 2009). Increasingly, too, ICTs are becoming more affordable to those Collier, in Spence \& Smith (2009), tag the "bottom billion" or "next billion" or "bottom of the pyramid", thus empowering the world's poorest and offering them, at the same time, massive opportunities and possibilities that were considered mere Shangrila many years ago (Imhonopi \& Urim, 2013). In this instance, mobile phones, laptops, Tablets, IPads, internet services and other ICT tools/services are no longer premium goods affordable only by the elite in the society. In Nigeria, Ghana and other African countries, mobile phones and new technologies like IPads, notebooks and Tablets are now used by low-income earners with even beggars on the streets clutching onto their mobile phones.

The impact of ICTs has virtually diffused through all sectors, forcing technological changes and creating a culture of dependence on technology. In Nigeria, the presence of ICTs has become ubiquitous and its knowledge has deepened. Many countries now regard the understanding of ICTs and mastering of their basic skills and concepts as part of the core of education, alongside reading, writing and numeracy (UNESCO, 2002). ICTs have also permeated the business environment, underpinned the success of modern corporations, strengthened value chains and provided governments with an efficient infrastructure for e-governance and e-citizen interface. Additionally, ICTs add value to the processes of learning, and organises and manages learning institutions across the spectrum.

ICTs have been reported to have played a great role in redefining education across the continuum (from the core to the periphery). It has brought massive regeneration and invigoration to teaching, research and learning and enhanced teacher-student interface by creating multiple channels of interaction. Several studies have highlighted the role ICTs 
have played in repositioning education in Nigeria at the primary, secondary and tertiary levels (Agbetuyi \& Oluwatayo, 2012; Imhonopi, 2009; Imhonopi \& Urim, 2011b; Nwosu \& Ogbomo, 2011). Although existing challenges remain, the future seems to point to the reliance of the educational system on ICTs in developed and developing nations. The focus of this paper, therefore, is to examine the role ICTs are playing in higher education in the country. This study is significant because education, especially higher education, is a key component of the human development mix of any country and harnessing ICTs to drive the process may bring about the expected dividends of literacy, industrial development and human progress much more speedily. The paper examines the various ways ICTs have proved useful in higher education in Nigeria, the challenges higher education faces in optimising the use of ICTs for teaching, research and learning and what can be done to improve the existing situation.

\section{Conceptual and Theoretical Matrix}

\subsection{ICTS Defined}

According to Garai (2006), ICTs cover Internet service provision, telecommunications equipment and services, information technology equipment and services, media and broadcasting, libraries and documentation centres, commercial information providers, network-based information services, and other related information and communication activities. For Chowdhury (2000) and Imhonopi \& Urim (2004), ICTs also encompass technologies that can process different kinds of information (voice, video, audio, text and data) and facilitate different forms of communications among human agents, among humans and information systems, and among information systems. Broadening this conversation, Imhonopi \& Urim (2012) argue that ICTs are modern technologies that facilitate information gathering, processing, transmission and storage and comprise hardware and software components that can be put to heterogeneous use through digitalisation connecting individuals and institutions over wide swathes of a geopolitical area. They further assert that the emergence of ICTs has provided the means for faster and better communication and utilisation of information between and for users, be they individuals, groups, businesses, organisations or governments.

\subsection{Higher Education Defined}

Education has remained at the top of the development agenda in Nigeria, nay Africa. On one hand, basic education in Africa is championed by Education for All (EFA) and the Millennium Development Goals (MDG) as a key factor for the reduction of poverty while the World Bank and other international organisations under the World Conference on Higher Education (WCHE) have given greater recognition to the critical role of higher education in building the knowledge economy and enhancing economic development in Africa (Mohamedbhai, 2008). This has put higher education on the top of the political and economic agendas of most, if not all, African countries.

Simply put, higher education refers to the universities in some contexts, but generally the term represents postschool, postsecondary or tertiary institutions and includes roles played by other more vocationally or technologicallyoriented institutions. According to Mohamedbhai (2008), although higher education and tertiary education are often used interchangeably, the term "higher education" represents all forms of organised educational learning and training activities beyond the secondary level. These may be at universities, polytechnics, training colleges as well as in all forms of professional institutions, among others. Higher education has been seen as a critical component of human development indices and a key driver to economic and national development of countries. Therefore, higher education is relevant to human development, capacity development and it plays an important role in providing high-level manpower in areas pertaining to social and economic development and in promoting research. The World Bank (2002) affirms that tertiary education is essential for the facilitation of nation building and also for the promotion of greater social cohesion, inspiring confidence in social institutions, as well as encouraging democratic participation through open debate. Higher education also brings about an appreciation of diversity in gender, ethnicity, religion and social class. Many individuals consider higher education as a major avenue for social mobility and a carte blanche for moving up the upper echelons of society (APEID-UNESCO, 2006).

\subsection{Political Economy Theory}

Political economy is a variant of the Marxist paradigmatic postulations. The theory is very apposite in explicating the state of higher education in Nigeria especially the incorporation of ICTs in driving higher education across the continuum and 
the endogenous challenges this process faces. The political economy theory is an ideological thrust that seeks to locate the challenges in the society or explain social phenomena by identifying the linkages that exist between political and economic forces. Core Marxian postulation identifies the economy or the substructure as the basis for all social realities. That is, the economy and the forces that control it are the same that define the complexion and content of the legal regime, political thought and system, educational process and system, cultural thought, religion and all forms of social institutions and conversations. Simply put, the economy is what defines the shape and character of these superstructure elements. In turn, the political realm, for instance, also shapes the economic system. It is evident in Nigeria, as well as in many African countries, that the political elite are mostly the economic elite. They control not only the political paraphernalia of the state but also the economic substructure. Some hijack the political arena through the control of the economic realm while others through political stagecraft become hegemonic forces within the economic superstructure. Thus, the problematic in Higher education in Nigeria is patent. This is because the present state of Nigeria's higher education is a reflection of the management crises, inept and visionless national leadership, infrastructural decay, poor funding, corruption-laden political elite, lack of prioritisation of government investments, outright negligence and many other factors locatable within the political-economic embryo of the Nigerian state. To unentangle higher education in the country from the limitations it is fraught with, government needs to seize the moment to reprioritise and locate higher education as an important item on the development agenda if it is to realise its Millennium Development Goals and beyond these, generate the right manpower the country needs to drive its industrial development efforts and lubricate the higher education sector, thus making Nigeria competitive in the comity of nations. One of the important strategies government can utilise in consummating this objective is to invest more in ICTs, as it has been agreed that ICTs have the potential to regenerate higher education across the continuum, and equip higher education products in the country with the right skills set, mindset and abilities that can make them ably compete with citizens of other nations in the global marketplace of ideas, labour, innovation and technology. Through ICTs, Nigeria can reach many more Nigerians with its higher education programmes through different technology-aided learning and teaching channels thereby bridging the urban centre-rural area higher education divide and creating multiple opportunities for citizens. Policies in the political space have to be carefully crafted to enable government realise these objectives. Also, entrenched encumbrances in the way of higher education development in the country need to be removed through political will and the commitment of adequate resources within a public-private partnership paradigm to invest in and drive higher education in Nigeria.

\section{Existing Use and Benefits of ICTs in Higher Education in Nigeria}

The use of ICTs within academia has become a modus vivendi for modern academics and students so much so that there is an inextricable intertwinement between ICTs and academic processes within higher educational institutions in Nigeria. A closer look at the existing use and benefits of ICT tools in higher education in Nigeria reveals the following:

i. Computers: Laptops \& Desktops: Higher education in Nigeria across a wide continuum has been enabled by the use of computers, including laptops and desktops. Academics and students now use these ICT tools as a medium to type, process and store their work for later use. Before the advent of mobiles such as iPhones, iPods, iPads and Tablets, $20^{\text {th }}$ century academia depended hugely on laptops and desktops for data generation, conversion and storage. Teaching and research are, therefore, enhanced by these tools.

ii. PowerPoint: Gradually, classroom teaching is made possible through PowerPoint presentations which bring more life, interactivity and connectivity to pedagogy. Teaching is no more a stale, blackboard, chalk and talk phenomenon but is now typified by visual as well as audio learning processes which enhance learning results.

iii. Email: Many academics and students now rely on emails to sustain interaction and improve communication between and among themselves. Through emails, these days, assignments are given to students and also submitted to tutors, research such as e-interview can be conducted, academic questions can be asked and tutors can reach out to their students, among others. Emails have become so useful to higher education that it is almost anathema not to have one as an academic or a student.

iv. Online Peer Review: Recently, peer review, which is an important process or activity that enhances the quality of research and academic works has been digitalised. For instance, junior researchers can send draft copies of their works electronically to the email addresses of (their) senior colleagues/experienced researchers for review while the latter will download these works on their laptops or mobiles, read and review the work to be sent back the same way, electronically. This process saves both parties the use of papers, is cost-effective, timely and fast. This process is enabled by the internet, which provides global connectivity for such interactions to take place. 
v. Collaborative Research: The distance-less and borderless nature of the internet has also helped in empowering collaborative research between and among researchers/academics living and working in far-flung continents. Nowadays, collaborative research works between African scholars and scholars living outside the continent are made possible. In the same vein, even within the African continent, scholars carry out transnational collaborations involving nationals of different countries within the continent. This brings robustness, freshness, diversity of thoughts, opinions and perspectives to bear on the outcome of such works. By such collaborations also, the international intelligentsia will pay more attention to research works coming from the continent and make use of these materials to further extend the frontiers of the global pool of knowledge.

vi. Digitalisation of School Processes: As part of the push for a green economy, higher educational institutions in Nigeria willy-nilly are forced to imbibe digitalisation as a global best practice. Nowadays, application and admissions into higher institutions in the country are conducted via online processes and these include payments, registration, admission, confirmation of acceptance and publishing of information for stakeholders. Similarly, e-communication channels are gradually replacing face-to-face communication processes and these make for speed, ease and time-saving advantages. Digital papers are also replacing physical papers which take up space and create environmental eyesore when they are being disposed. Also, physical libraries are gradually given way to the emergence of e-libraries. Thus, higher education in Nigeria is not left behind in this regard.

vii. Websites: Most, if not all, higher educational institutions in Nigeria have a website or multiple websites that contain their corporate information and other details. Through this forum, higher institutions are able to connect with their students and staff, and meet the needs of other stakeholders. Also, websites have become marketing tools for higher institutions including remaining communication channels to explain the programmes and activities of the respective institutions. Higher education in the country now flourishes through websites of post-secondary institutions who continuously invest in their websites to achieve their multiple benefits or objectives.

viii. E-conferencing: Higher education in the country is gradually focusing on harvesting the benefits of econferencing. Through this process, distance learning opportunities can be created or sustained and research teams across wide distances can meet to collaborate or share findings that could enhance the quality of research outcomes. Another popular aspect of this use is e-interview. For instance, a few universities, like Covenant University, have begun to use online interview to engage the services of academics of Nigerian and foreign origins who live outside the shores of the country. Akin to this is e-recruitment and e-HR management.

ix. E-learning tools (including web 2.0): According to Imhonopi \& Urim (2011), there are several e-learning tools that are gradually becoming the norm in and for higher education in Nigeria. These include online resources, tools, software and platforms that enable language teaching and learning within and outside the classroom. They include the internet, blogs, e-groups, SMSs, socialising portals, e-dictionaries, e-encyclopedia, PowerPoint presentations with audio and video clips, webcasting, and audio-video materials. Others are teleconferencing (text-based, video and audio conferencing), interactive television, digital satellite television, audio graphics, internet chats, bulletin boards, wikis, podcasting, electronic portfolios, conference alerts and WebQuests among others.

x. Mobiles: Although not yet fully deployed, to a large extent, higher education in Nigeria currently uses mobile technologies such as mobile phones, Tablets, IPads, iPods and others to prosecute learning, teaching and research efforts. These instruments help for the easy generation, processing, storage and transmission of data. They also provide multimedia advantages which offer multiple learning advantages and real time communication between and among academics and their students.

xi. Online publishing: Before the emergence of ICTs, publishing of research and academic works was done physically and only hard copies in their various formats were available. A major disadvantage this form of publishing had was that journal materials were not easy to access as only those who had access to the print copies could read them. This situation limited knowledge expansion because only few people could access the research works that could have enhanced their epistemic bases. However, nowadays, ICTs have introduced online publishing with the advantage of open access publications which make it easy for scholars to access these pieces of information and profit thereby. Online publishing, therefore, expands global epistemic bases. 


\section{Challenges Facing ICT and Higher Education in Nigeria}

The challenges facing higher education in Nigeria are as follows:

i. Poor funding has remained a tall challenge for robust and effective higher education in Nigeria. Granted that funding higher education in any economy, whether developed or developing, is expensive, in Nigeria, higher education has received several knocks from the establishment as the government has failed in its commitment to invest heavily in the subsector. While government claims it suffers from paucity of funds, it is amazing when one considers the expensiveness of governance in Nigeria which if tamed could free funds for investment in education. According to Imhonopi \& Urim (2012), Nigeria has remained shamelessly scandalous in the area of the expensive cost of managing the democratic structures of the state and the people that run them. This is because of the entrenched corruption at the centre down to the constituent states and local authorities, the multiplication of government ministries, departments and agencies (MDAs), the bloated civil and public services, the self-approved jumbo pays and perks for members of the executive and legislative branches, and the boiling internal agitation arising from ethnic mistrust and suspicion within a tensed climate of religious and ethnic cleavages, spiced by unpopular rule, poor standard of living and grinding poverty. A restructuring of the entire governance structure in Nigeria, with focus on reducing cost of governance, will be a step in the right direction.

ii. Spotty power supply is also another challenge that throttles efforts to mainstream ICTs for higher education development in Nigeria. Nigeria currently produces less than 4,000 megawatts of electricity which is incredibly insufficient to meet the needs of Nigeria across all sectors, including the education sector. Since ICTs are powered directly and/or indirectly by one form of energy or the other, correcting the flaws/challenges inherent in the power sector and regenerating the sector to meet the needs of a modern state will provide the needed boost for ICT integration in higher education in Nigeria.

iii. Lack of infrastructure is another challenge to higher education in Nigeria. There are mountains of evidence showing that existing higher institutions in the country lack the requisite physical classes, teaching and learning tools, and modern ICTs that could help them conduct teaching, learning and research processes in a clement ecology. This is why, for instance, the Academic Staff Union of Universities always goes on strike to draw government's attention to the sorry plight of Nigerian universities. Until the infrastructure deficits in place are arrested, higher education in the country may continue to slide into decay.

iv. A notable problem facing higher education in the country is the question of brain drain. There is a massive exodus of Nigerian scholars, academics and professionals to Western countries to look for greener pastures as this corps of domestic intelligentsia has found it difficult to put up with the putrescence that characterises higher education management in Nigeria. According to Imhonopi \& Urim (2012), the aetiologies of brain drain in Nigeria are traceable to such inextricable conundrums as the breakdown of social infrastructure, low-income nature of academic work, corrupt and irresponsible political leadership, lack of commitment to and investment in the educational sector and the lack of development of other sectors and the general climate of ennui which typify academic modus vivendi. Imhonopi \& Urim (2012) submit that through brain drain, Nigeria, nay Africa, is losing its finest people to developed countries.

v. Official corruption and other vices within the governance plane have also created a serious conflation of forces to undermine higher education in Nigeria. The implication of the several financial crimes committed by elected and appointed government officials leaves the government prostrate to meet its obligations towards higher education development in the country.

vi. Lack of political will and prioritisation of investments by government are other problems that frustrate ICT and higher education development in Nigeria. The government, represented by some of its eggheads, seems to be caught in endless and meaningless vacillations because it does not have the political will to bring about the needed turnaround in higher education in the country nor does it prioritise its investment. For instance, the government spends so much on needless items of recurrent expenditure, some of the monies which could have been channelled into education funding.

vii. Lack of investment in ICTs for higher education development is another drag on the development of the subsector. No nation that wants to lead others hates or despises technology. Without technology tools as provided by ICTs, higher education will be greatly stifled with the lack of optimisation of many benefits.

Unless these drawbacks are reined in, higher education in Nigeria may not benefit much from ICTs. Government, therefore, must become seriously committed to the issue of adequate and timely investment in ICTs to drive the country's 
educational system, especially at the higher level.

\section{Conclusion}

Without a doubt, ICTs will continue to refine and define human interactions and social relations within society for many years to come. In fact, it appears every realm of human endeavour is at the mercy of ICT tools and this seems to continue incrementally ad infinitum. Higher education, a subset of the educational system, will not be enhanced or promoted in Nigeria if the existing political and economic forces throttling it are not addressed. If higher education is critical for national development, economic growth, national integration, better standard of living for citizens and it generally engenders citizen empowerment, then, it will be right if government pays more attention to it. Employing frugal measures or lean management in governance, curbing or eliminating the manifested strands of corruption in governance, reprioritising investment in education and massive ICTs deployment in higher education together with the provision of the requisite infrastructure such as stable power supply will hasten the needed turnaround of higher education than hinder it. Nigeria cannot afford to toy with its educational system. Ignoble factors which have continued to make higher education unattractive to many Nigerian academics, professionals and researchers and which ultimately force them to emigrate to other more developed climes must be identified and eliminated. Improved funding, which is a sine qua non to improved higher education in the country, can be achieved by eliminating all the loopholes through which state funds are diverted to private bank accounts and pockets. The monster of corruption also has to be tackled vigorously. Until the challenges in the Nigerian political economy vis-a-vis higher education are addressed, and ICTs are invested in and deployed for greater use in higher education development, the future of the country's higher education and its products may continue to fade.

\section{References}

Agbetuyi, P. A. \& Oluwatayo, J. A. (2012). Information and Communication Technology (ICT) in Nigerian Educational System. In Mediterranean Journal of Social Sciences. Vol. 3 (3) September.

APEID-UNESCO, (2006). Higher Education in South-East Asia. Bangkok: UNESCO.

Chowdhury, N. (2000) 'Information and Communications Technologies and IFPRI's Mandate: A Conceptual Framework.' Sept. 18, 2000. http://www.ifpri.org/divs/cd/dp/ictdp01.pdf.

Garai, A. (2005). Processes and appropriation of ICT in human development in rural India: A Theoretical approach. A OWSA Briefing Paper. New Delhi: OneWorld South Asia.

Imhonopi, D. \& Urim, U. M. (2011). Information and Communication Technologies (ICTs): New Media Tools for Language Teaching and Learning in Tertiary Institutions in Nigeria. Paper prepared for the 8th ELTT Annual Conference on Resources and Resourcefulness in English Language Teaching and Learning in the $21^{\text {st }}$ Century held at the Department of Communication and General Studies, University of Agriculture, Abeokuta, Ogun state between July 12th - 15th.

Imhonopi, D. \& Urim, U. M. (2011a). "Maximising ICT for Quality Research and Teaching in Tertiary Institutions in Nigeria." Journal of Society and Development, Vol. 1, No. 3, pp. 44-58. Abraka, Nigeria: Interdisciplinary Journal of the Nigerian Sociological Society, Delta State University.

Imhonopi, D. \& Urim, U. M. (2011b). "The Impact of Internet Services on the Research Output of Academic Staff of Selected State Universities in South-Western Nigeria." International Journal of Information and Communication Technology, Vol. 8, No. 1, pp. 920. Niger State, Nigeria: The Information Technologist, Federal University of Technology.

Imhonopi, D. (2009). Influence of Utilisation of Internet Services on Teaching and Research Output among Academic Staff of Selected Universities in South-Western Nigeria. An unpublished PhD Thesis submitted to the Department of Sociology, University of Ibadan, Ibadan.

Imhonopi, D. \& Urim, U. M. (2012). "Nigeria's Expensive Democracy: A Confederal Option for Development." The Journal of Sustainable Development in Africa (JSDA), Vol. 14, No. 7, pp. 70-80. Pennsylvania, USA: Clarion University of Pennsylvania.

Imhonopi, D. \& Urim, U. M. (In Press). "The Impact of Globalisation on the Educational System in Nigeria." Asian Social Science, Canada. Vol. 8, No. 2.

Imhonopi, D., Urim, U. M. \& Igbadumhe, F. A. (2013). "Information and Communication Technologies and Human Development in Nigeria: Forging the Nexus." International Journal of Information Communication Technologies and Human Development, Vol. 6 , No. 1. Pennyslvania, USA: IGI Global.

Mohamedbhai, G. (2008). The Effects of Massification on Higher Education in Africa. Being a project sponsored by the Working Group on Higher Education (WGHE) of the Association for the Development of Education in Africa (ADEA) and the Association of African Universities (AAU), Ethiopia.

Nwosu, O. \& Ogbomo, E. F. (2011). ICT in Education: A Catalyst for Effective Use of Information. In Pacific Northwest Library Association, PNLA Quarterly, Volume 75, no. 4.

Okafor, E. E., Imhonopi, D. \& Urim, U. M. (2011). "Utilisation of Internet Services and Research Outputs In Private Universities In South- 
Western Nigeria" International Journal of Emerging of Technologies and Society (IJETS), Vol. 9, No. 2, pp. 135-151. Australia: Swinburne University of Technology.

Salawu, B. A. (2008). "ICTs for Sustainable Development: The Nigerian Experience." Information, Society and Justice, Volume 1 (2); pp. $115-135$.

Spence, R. \& Smith, M. (2009). Information and Communication Technologies, Human Development, Growth and Poverty Reduction: A Background Paper. ...: IDRC, April 28.

UNESCO. (2002). Information and Communication Technology in Education: A Curriculum for Schools and Programme of Teacher Development. France: UNESCO, Division of Higher Education.

World Bank (2002), Constructing Knowledge Societies: New Challenges for Tertiary Education. Washington, D.C.: The World Bank. 
